\title{
RAT THYMOCYTES DIFFERENTIATION IN ADULT THYMUS ORGAN CULTURE
}

\author{
RAKIN ANA*, KUŠTRIMOVIĆ NATAŠA*, KOSEC D*, ŽIVKOVIĆ IRENA*, JANKOVIĆ I** \\ and MIĆĆC MILEVA** \\ *Immunology Research Center "Branislav Jankovic", Institute of Virology, Vaccines and Sera \\ "Torlak", Belgrade, Serbia \\ **University of Belgrade, Institute for Medical Research, Belgrade, Serbia \\ (Received $3^{\text {rd }}$ June 2011)
}

To investigate the differences between thymocytes development in vivo and in vitro, thymus lobe fragments from 12-weeks old male Albino Oxford rats were cultivated over a 7-days period. In the controls and cultivated thymic lobes fragments were evaluated and the viability, apoptosis and cell cycle of thymocytes, as well as the histological characteristics of thymic tissue. Additionally, we analyzed the expression of CD4, CD8 and TCR $\alpha \beta$ on thymocytes by flow cytometry. The obtained results showed that thymus cellularity decreased during cultivated time due to expanded apoptosis, decreased proliferation and the absence of progenitors reseeding thymus. The relative proportion of thymocyte subsets in the first 24 hours of culture remained similar as in the control. However, cultivation for 3 and 7 days modulated the relative proportions between thymoctye subsets. The percentage of DP $T C R \alpha \beta^{\text {low }}$ increased, DP TCR $\alpha \beta^{\text {hi }}$ subset remained unchanged, both $S P T C R \alpha \beta^{\text {hi }}$ subsets decreased while the same mature SP phenotype dominated in culture media. These results demonstrate that cultivated thymic fragments retain the capacity for $T$ cell development, although cultivation modulates this process. emigrants

Key words: ATOC, rat, $T$ cell development, thymus, thymus

\section{INTRODUCTION}

Thymus is the primary lymphoid organ that provides specialized microenvironment for bone marrow-derived progenitor cells maturation in naive, immunocompetent $T$ cells. Developing thymocytes face a series of checkpoints including $\mathrm{T}$ cell receptor (TCR) $\beta$ gene rearrangement, $\beta$ selection and cell proliferation, dual coreceptor expression, TCR $\alpha$ gene rearrangement, positive and negative selection, lineage commitment and down regulation of inappropriate coreceptor expression. These processes take place in separate thymus microenvironments, defined by distinct stromal elements (Anderson et al., 2007; Correia-Neves et al., 2001 Gray et al., 2005; Starr et al., 2003). 
Concerning complexity of thymocyte maturation, immunologists and cell biologists developed in vitro systems for the study of thymocytes and thymic stromal cells development and function (Hare et al., 1999; Plum et al., 2000; Zhang et al., 2007). The first in vitro systems for studies of T cell development were thymocyte suspensions and thymus epithelial monolayer cell cultures. These cell cultures had been shown to be of little use for thymocyte differentiation studies since they often involve disruption of lymphoid and stromal cells interactions necessary for adequate T cell maturation (Anderson et al., 1994; Jenkinson and Anderson, 1994; Gray et al., 2005; Mohtashami and Zuñiga-Pflücker, 2006; Anderson et al., 2007).

The thymus organ culture (such as fetal, reagregate, adult, etc.) has the advantage in that it mimics normal development of mouse and rat T cells, in their natural three-dimensional microenvironment, preserving normal cell-to-cell interactions (Jenkinson and Anderson, 1994; Anderson and Jenkinson, 2000; Cardoso et al., 2006). Their advantage lies, also, in the possibility to study the particular influence of different substances and drugs on immune cells development in vitro and away from any influences outside the thymus (Woods et al., 2003; Zhang et al., 2007).

Adult thymus organ culture (ATOC) seems the right choice for studies concerning shaping and maintenance of $\mathrm{T}$ cell repertoire in postnatal/adult animals under normal and pathological conditions. Whalen et al. (1999) showed that rat ATOC recapitulates faithfully normal rat intrathymic T cell developmental kinetics and phenotypes, generating CD4 and CD8 single positive (SP) cells that up-regulate TCR. T cell maturation in rat ATOC is characterized by progressive cell maturation in the context of extensive cell death. The majority of thymocytes are either dead or dying by apoptosis. This extensive degree of cell death is consistent with the fact that, in normal rat thymus only 3-5\% of thymocytes passes strict selection and become T cells capable to emigrate into peripheral tissues (Ergoton et al., 1990; Whalen et al., 1999). The dramatic loss of cells seen during the first 5 days of culture is consistent with the in vivo life span of cells that fail to undergo positive selection (Merkenschlager et al., 1997; Ergoton et al., 1990; Surh and Sprent, 1994; Thomas-Vaslin et al., 2008). ATOC provides adequate microenvironment for T cells maturation not only for thymocytes proliferation and for gaining of $\mathrm{T}$ cell markers, but it also provides soluble factors included in triggering apoptosis.

Considering that data regarding T cell development in ATOC are very scarce, we cultivated thymus lobe fragments, originated from adult male Albino Oxford (AO) rats to investigate T cell development in ATOC during a one-week period, in order to compare adult rat thymocyte development in vitro and in vivo and if there are differences between these two systems to identify them.

\section{MATERIALS AND METHODS}

Animals

Adult inbred AO male rats, 12-weeks old were maintained in single cages under standardized conditions of humidity, light and temperature were used for 
this study. Food and water were available ad libitum. The Institutional Animal Care and Use Committee approved the experimental protocol.

\section{Chemicals and Materials}

Phosphate-buffered saline (PBS, pH 7.3); Fetal Calf Serum (FCS) and DMEM/F12 1:1 mixture with GlutaMAX I (avoid ammonia buildup) (Gibco, Invitrogen Corporation, Grand Island, NY, USA); Sodium aside $\left(\mathrm{NaN}_{3}\right)$ and HEPES (Sigma-Aldrich Chemie GmbH, Taufkirchen, Germany); Rounded sterile collagen sponges (Spongostan, Norderstedt, Germany); 6-well plates (Nunc, Denmark); Nitrocellulose filters $0.45 \mu \mathrm{m}$ pores (HAWP02500, Millipore, Bedford, USA).

Adult thymus organ culture - ATOC

A day before sacrifice rounded, sterile collagen sponges were cut into $0.5 \mathrm{x}$ $\varnothing 3 \mathrm{~cm}$ cylinders, placed in plate wells field with $4 \mathrm{~mL}$ of cultivating media and left in the incubator to soak overnight. Rats were sacrificed by cervical dislocation, thymuses taken out, separated into individual lobes, weighted and placed in Petrie dishes field with sterile, ice cold PBS supplemented with 5\% FCS and $0.01 \%$ sodium azide. Thymic lobes were cut in 6 pieces and thymic fragments (trough text thymic fragments are referred as thymic lobes) cultivated in individual wells of 6-well culture plates on nitrocellulose filters resting upon collagen sponges. Each well was added with $5 \mathrm{ml}$ of D-MEM/F12 media containing $15 \mathrm{mM}$ HEPES supplemented with $1 \times$ nonessential amino acids, $5 \times 10^{-5}$ M 2-mercaptoethanol (2-ME), $20 \%$ heat-inactivated FCS, penicillin $(100 \mathrm{U} / \mathrm{mL})$, streptomycin $(0.1 \mathrm{mg} / \mathrm{mL})$ and gentamicin $(125 \mathrm{ng} / \mathrm{mL})$. ATOC were cultivated at $37^{\circ} \mathrm{C}$ in a humidified atmosphere at $7 \% \mathrm{CO}_{2}$. The thymus tissue was maintained at gas-medium interface by collagen sponge cylinders support. Culture media was changed every day at the same time. After 1,3 and 7 days of culture thymus lobes fragments were taken out and used for histological analysis and flow cytometric evaluation of surface markers expression, apoptosis and cell cycle. Thymuses removed immediately after sacrifice were used as in vivo controls.

Preparation of thymocyte single cell suspensions

Single-cell suspensions were prepared by grinding thymus tissue between frosted ends of microscope slides in cold PBS containing $2 \%$ FCS and $0.01 \%$ sodium aside (PBS). The obtained single-cell suspensions were passed through a fine nylon mesh and after washing in cold PBS (three times) were counted in a standard haemocytometer. Thymocyte suspensions were adjusted to cell density of $1 \times 10^{7}$ cells $/ \mathrm{mL}$ PBS buffer. Single-cell suspensions of the each sample $(100 \mu \mathrm{L})$ were used for viable cell determination by Acridin orange/Ethidium bromide. The cells were stained with equal volumes of dyes mixture prepared immediately before analysis and cell suspensions were examined under Olympus $\mathrm{BH} 2$ fluorescence microscope (Olympus, Tokyo, Japan). Acridin orange stained viable cells (green fluorescence), while ethidium bromide stained apoptotic/dead cells with disrupted membranes (red fluoresce). Acridin orange and ethidium bromide positive cells were counted using a high power objective lens $(\times 100)$ independently by two observers (authors MM and JR). 


\section{ATOC emigrants}

Cells that leave thymic lobes during cultivation (called "emigrants") collected from the media and rinsed off nitrocellulose filter from each plate well were used for surface markers analysis by flow cytometry.

\section{Antibodies}

For immunofluorescence staining, the following mono- and polyclonal antibodies were used: fluorescein-isothiocyanate (FITC)-conjugated anti-CD4 (W3/25, Serotec, Oxford, UK), phycoerythrin (PE)-conjugated anti-CD8 (OX-8, Serotec, Oxford, UK) and biotin-conjugated anti-TCR $\alpha \beta$ (R-73, BD Bioscience, San Jose, CA, USA). Controls included irrelevant isotype matched antibodies tagged with FITC, PE and biotin (BD Bioscience) and streptavidinperidinchlorophyll protein (Streptavidin Per-CP) (BD Bioscience).

\section{Flow cytometry}

Three- and one-color immunostaining was used for cell surface markers analysis by FACScan flow cytometer (Becton Dickinson, Mountain View, CA, USA). Thymocyte suspensions $\left(1 \pm 0.5 \times 10^{6} / 100 \mu \mathrm{L}\right)$ were incubated simultaneously with an appropriate amount of specific monoclonal antibodies against rat $\mathrm{CD} 4, \mathrm{CD} 8$ and $\mathrm{TCR} \alpha \beta$ for $30 \mathrm{~min}$ at $4^{\circ} \mathrm{C}$ in the dark. After washing in PBS buffer, cells were incubated with streptavidin-PerCP under the same conditions. After washing in PBS buffer, single-cell suspensions were fixed in $0.5 \mathrm{~mL} 1 \%$ paraformaldehyde and kept in the dark at $4^{\circ} \mathrm{C}$ until analysis. Usually, $2 \times 10^{4}$ cells for three-color analysis were used. Non-specific IgG isotype matched controls were used for each fluorochrome type to define background staining. Forward light scatter and size scatter gates were set to exclude dead cells and debris. Samples were analyzed using Cell Quest Software (Becton Dickinson).

\section{Detection of apoptotic thymocytes}

Merocyanine 540 (MC 540) dye, similar to annexin V, that binds to phosphatidyl serine exposed on membrane surface apoptotic thymocytes was used for the detection of apoptosis by flow cytometry. The percentage of apoptotic cells detected by MC 540 has been shown to be equivalent to that obtained by propidium iodide (PI) and annexin V (Laakko et al., 2002). Immediately before analysis by flow cytometer, $5 \mu$ l of MC $540(1 \mathrm{mg} / \mathrm{mL}$ redistilled water) was added into thymocyte suspensions, in concentration of $1 \times 10^{6}$ cells per $\mathrm{mL}$ of PBS, and gently shaken. Samples were analyzed using Cell Quest Software (Becton Dikinson).

Cell cycle analysis

Cell cycle analysis was performed by staining with PI. Briefly, thymocyte suspensions were fixed by drop wise addition of ice-cold ethanol, incubated 30 min at $37^{\circ} \mathrm{C}$ with heat-inactivated RNAse and with PI for $10 \mathrm{~min} / \mathrm{room}$ temperature/dark. Cell cycle analysis was performed on the same day by flow cytometer utilizing doublet discrimination module (DDM) and analyzed by Cell Quest Software (Becton Dikinson). 
Histology

The thymus lobes were removed, dried and quickly frozen at $-70^{\circ} \mathrm{C}$. Cryostat sections, $5 \mu \mathrm{m}$ thick, were stained with Haematoxylin and Eosin, and analyzed under an Olympus $\mathrm{BH} 2$ microscope.

Statistical analysis

Presented data were calculated from four individual experiments conducted in the same manner. The results were expressed as the mean values \pm SD or the median (max, min). Values were compared by nonparametric Mann-Whitney $U$ test using the program SPSS 10 for Windows. Differences at $p<0.05$ were accepted as the level of significance.

\section{RESULTS}

The number of thymocytes in ATOC was diminished compared to controls The number of thymocytes was reduced in the cultures $\left(2.61 \pm 0.41 \times 10^{8}\right.$ on day $1 ; 2.47 \pm 0.56 \times 10^{8}$ on day $3 ; 2.69 \pm 0.52 \times 10^{8}$ on day 7 ) compared to the values found in the controls $\left(7.17 \pm 0.9 \times 10^{8} ; p<0.001\right.$; Figure 1$)$. The number of viable cells was significantly lower at the third and seventh day of culture compared to day 1 of ATOC (Figure 2).

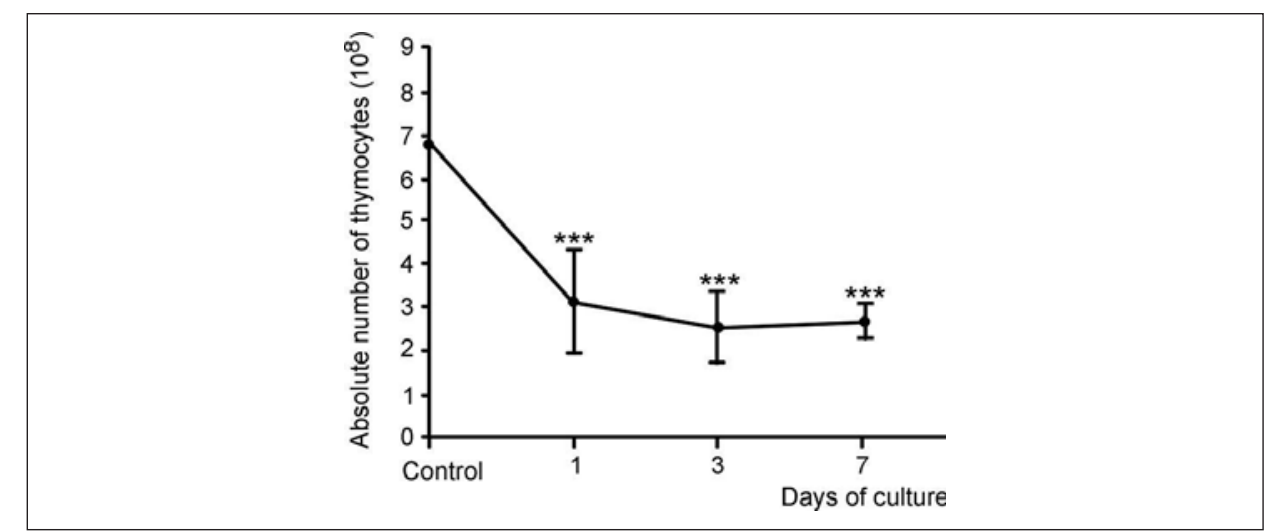

Figure 1. Absolute number of thymocytes in the control thymic lobes of adult male AO rats and at determined time points of organ culture (days 1, 3 and 7). Each data point represents mean \pm SD of 12 thymic lobes

The apoptosis of thymocytes raised in ATOC over time

To determine the number of apoptotic cell MC 540 was used. According to Mower et al. (1994) live cells and three apoptotic subpopulations of thymocytes: a pool of thymocytes in the early phase of apoptosis, a hypodiploid cells in developed apoptosis and thymocytes in the late phase of apoptosis/necrosis were gated (Figure $3 a$ ). The percentage of live cells was significantly decreased throughout the period of observation $(p<0.001)$ compared to the values found in 
the controls (Figure 2b). The percentage of apoptotic thymocytes significantly increased in the early and in developed phases $(p<0.01$ day $1 ; p<0.001$ days 3 and 7 vs. controls) and in the late phase of apoptosis $(p<0.05$ days 1 and 3 vs. controls (Figure $3 \mathrm{~b}$ ). Moreover, the percentage of thymocytes was significantly increased in the early and in developed phases of apoptosis on the third and seventh day of ATOC compared to the values found on the first day $(p<0.001$, Figure $3 b)$.
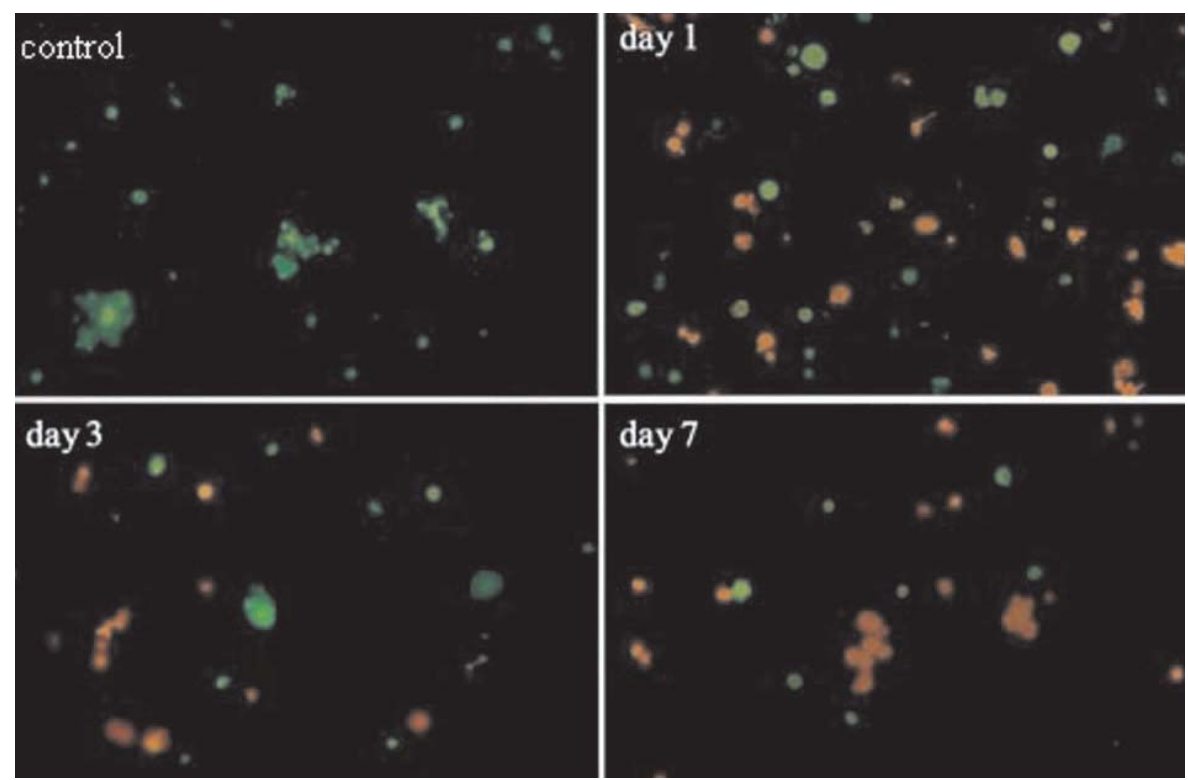

Figure 2. Viable (green) and apoptotic (red) cells in the control and cultivated thymic lobes. Images are representative of four independent experiments. The viability of thymocytes per lobe was determined by ethidium bromide and acridin orange staining method. Original magnification $100 \times .(n=12)$ thymic lobes. ${ }^{* *} p<0.001$ day 1,3 and 7 vs. controls; a $p<0.05$ day 3 and 7 vs. day 1

Cell cycle of thymocytes was disturbed in ATOC compared to controls

Presented data show a progressive increase in the percentages of cells in sub-G1phase (hypodiploid content of DNA) and cells in S and G2/M phases (hyperdiploid content of DNA), while the percentage of thymocytes in G0/G1 phase (diploid content of DNA) progressively declined, over the 7-day period of culture compared to controls (Figure 4a). After 1 day of cultivativation the percentage of thymocytes in sub-G1 phase was increased $(p<0.05)$, and in G0/G1 phase was decreased ( $p<0.05$; Figure $4 b)$. After 3 and 7 days in ATOC, in addition to changes in sub-G1 and G0/G1 phases, an increase in the percentages of cells in $S$ and $G 2 / M$ phases $(p<0.05)$ was detected. Changes regostered in G0/G1 and S and G2/M phases at days 3 and 7 of culture showed to be significant 
Acta Veterinaria (Beograd), Vol. 61, No. 5-6, 461-478, 2011.

Rakin K Ana et al.: Rat thymocytes differentiation

in adult thymus organ culture

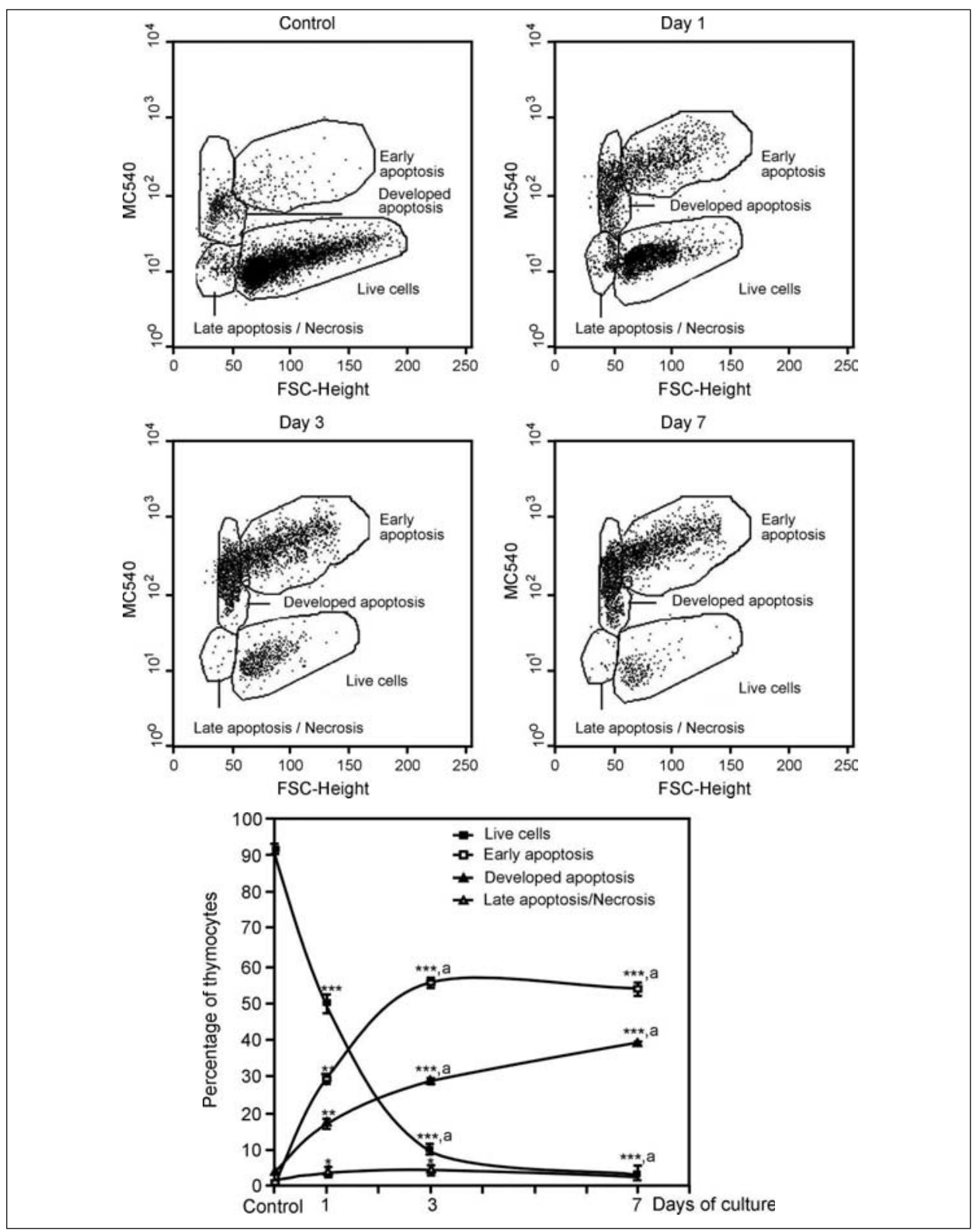

Figure 3. The percentage of apoptotic thymocytes determined by flow cytometry using dye Merocyanine 540, in the control and cultivated thymic lobes. Representative dot plots display the live cells, cells in early, developed and late phases of apoptosis (a). Graphic shows the relative proportion of live and apoptotic cells in the each phase of apoptosis. The results are presented as mean $\pm S D$. $(n=12)$ thymic lobes. ${ }^{*} p<0.05$; ${ }^{* \star} p<0.01 ;{ }^{* \star} p<0.001$, day 1,3 and 7 vs. controls; ${ }^{a} p<0.001$, day 3 and 7 vs. day 1 
$(p<0.05)$ compared to the values obtained after 24 hours in the culture (Figure $4 b)$.

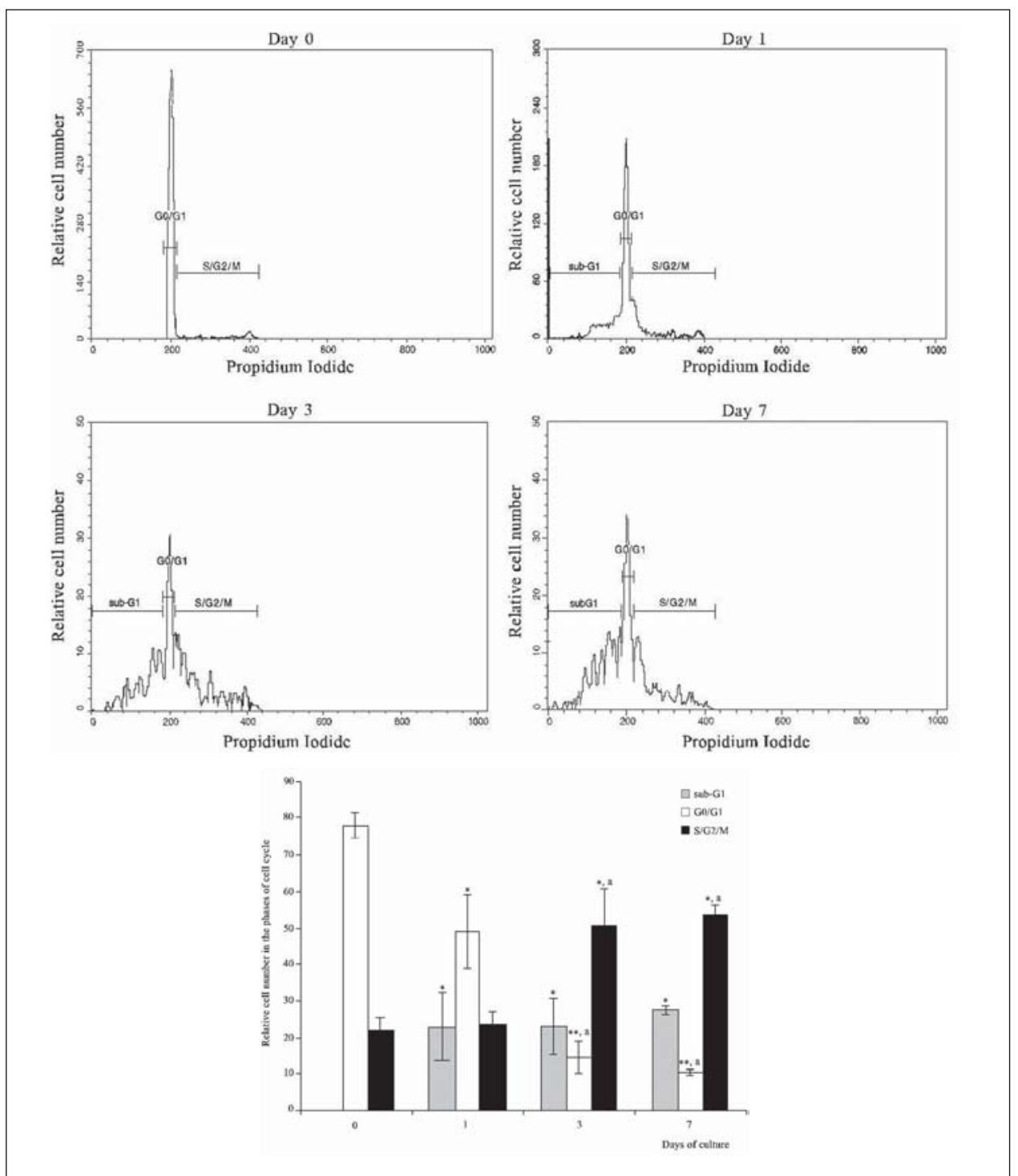

Figure 4. Distribution of thymocytes in phases of the cell cycle in the control thymus and in the thymic lobes after 1,3 and 7 days in culture (a). Cell-cycle distribution is determined by flow cytometry analysis of DNA content in propidium iodide (PI) stained cells. The PI fluorescence is depicted by linear scale. The changes of the thymocytes distribution in all phases of the cell cycle are shown as graphic (b). Values represent mean \pm S.D. $(n=12)$ thymic lobes. ${ }^{* *} p<0.01 ;{ }^{*} p<0.05$ days 1,3 and 7 vs. controls; $\mathrm{a} p<0.05$ days 3 and 7 vs. day 1 
Acta Veterinaria (Beograd), Vol. 61, No. 5-6, 461-478, 2011.

Rakin K Ana et al.: Rat thymocytes differentiation

in adult thymus organ culture

Cultivation changed morphological characteristics of thymus

Analysis of thymus lobes sections showed that cultivation leads to reduction of the cell number in the outer part of the thymic cortex, occupied mostly by immature DP cells subjected to massive apoptosis. An increased number of cells displaying various stages of apoptosis was observed, also. The degree of these changes correlates with time duration of the culture (Figure 5b, c, d).
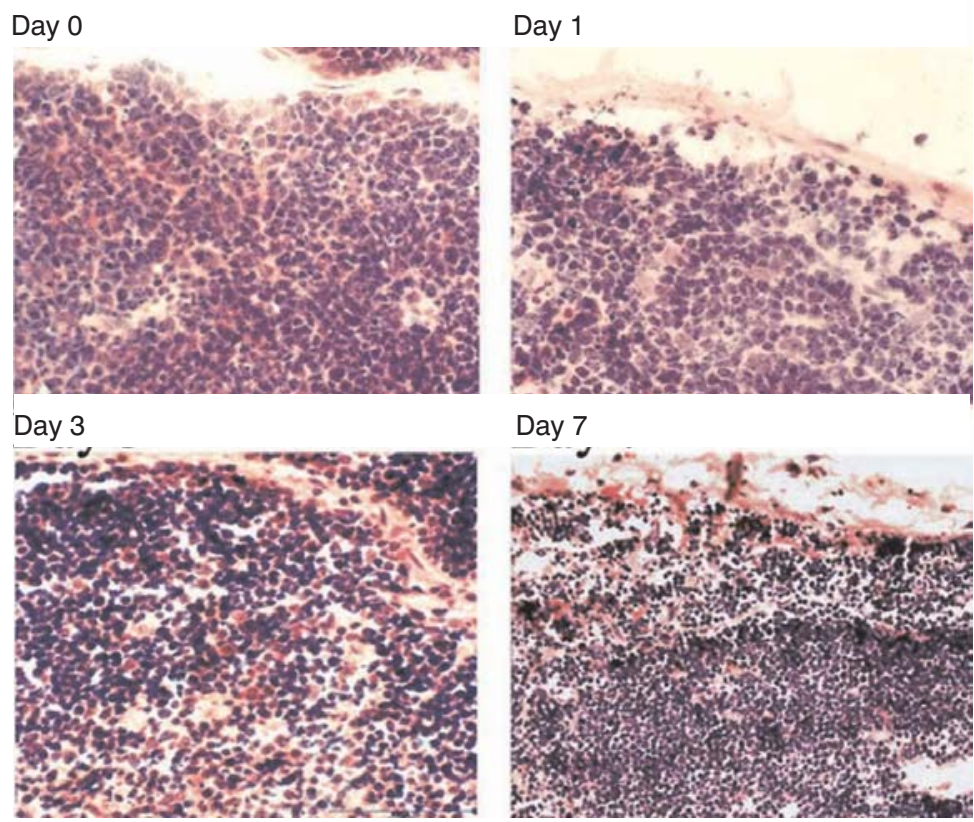

Figure 5. Microphotographs of the frozen sections of adult rats thymic lobes, taken before culture (control) and after cultivation (1, 3 and 7 days), stained with hematoxylin and eosin. Reduction in cell number is visible in the outer cortex of the thymus after 1 (b), 3 (c) and 7 (d) days of cultivation

Relationships between thymocyte subpopulations changed during ATOC The results showed that the percentage of double positive (DP, CD4 $\left.{ }^{+} \mathrm{CD} 8^{+}\right)$ cells gradually rises, while the percentages of both subsets of single positive (SP $\left.\mathrm{CD} 4, \mathrm{CD}_{4}{ }^{+} \mathrm{CD} 8^{-} \mathrm{SP} \mathrm{CD} 8, \mathrm{CD}^{+}{ }^{+} \mathrm{CD} 4^{-}\right)$and double negative (DN, CD4 ${ }^{-} \mathrm{CD} 8^{-}$day 1 and 3 of culture) cells decline during the 7-day period of culture, compared to controls (Figure 6a). Cultivation of the thymic lobes for 24 hours significantly reduced the percentage of DN cells $(p<0.01)$, while there was no significant change in the relative proportion of the remaining thymocyte subpopulations, compared to the values found in the control thymic lobes. In lobes cultivated for 3 and 7 days the percentages of the cells expressing either CD8 $(p<0.001$, on day 3 and 7$)$ or CD4 ( $<<0.05$ on day 3 and $p<0.01$ on day 7$)$ were lower than in the controls, while the percentage of DP cells increased $(p<0.05)$. The percentage of 
the cells negative for the both CD4 and CD8 markers was significantly decreased on day 3 ( $p<0.05$ vs. controls), and increased on day 7 ( $p<0.05$, vs. controls, Table 1).

Table 1. Proportions of the four thymocyte subpopulations, defined according to CD4 and CD8 expression, in controls and 1, 3 and 7 days cultivated adult thymus lobes

\begin{tabular}{|c|c|c|c|c|}
\hline \multirow{2}{*}{$\begin{array}{c}\text { Thymocyte } \\
\text { subpopulations }\end{array}$} & \multicolumn{4}{|c|}{ Percentage of thymocytes } \\
\cline { 2 - 5 } & Controls & 1 day & 3 days & 7days \\
\hline \hline CD4-CD8 $^{-}$ & $3.14 \pm 0.31$ & $0.60 \pm 0.07^{* *}$ & $1.20 \pm 0.05^{*}$ & $4.85 \pm 0.25^{*}$ \\
\hline CD8+CD4 $^{+}$ & $81.2 \pm 2.30$ & $84.23 \pm 3.46$ & $91.80 \pm 0.89^{* *}$ & $93.45 \pm 4.20^{\star *}$ \\
\hline CD8+CD4 $^{-}$ & $6.82 \pm 1.45$ & $5.23 \pm 1.23$ & $2.95 \pm 1.29^{*}$ & $1.42 \pm 0.06^{* *}$ \\
\hline CD8-CD4 $^{+}$ & $8.97 \pm 1.49$ & $10.06 \pm 3.44$ & $4.10 \pm 1.69^{*}$ & $0.45 \pm 0.021^{* * *}$ \\
\hline
\end{tabular}

The results are expressed as the mean $\pm S D$. ${ }^{*} p<0.05 ;{ }^{* *} p<0.01 ;{ }^{*}{ }^{*} p<0.001$; v.s. control

Decrease of the total thymocytes number was accompanied by decrement of the absolute number at all thymocyte subpopulations in the cultivated thymic lobes (at all investigated time points) compared to the thymocyte number found in the control thymic lobes (Figure 1).

The differentiation of thymocytes in ATOC was modulated by cultivation

In control thymic lobes (day 0 ) $42.22 \%$ cells belonged to TCR $\alpha \beta^{-}$ thymocytes, $42.27 \%$ thymocytes expressed TCR $\alpha \beta^{\text {low }}$ and $15.54 \%$ of thymocytes expressed high level of TCR $\alpha \beta$. Cultivation of thymic lobes for 1, 3 and 7 days, significantly decreased the percentage of cells expressing TCR $\alpha \beta^{\text {hi }}(p<0.01)$ and altered the relationship between $\mathrm{TCR} \alpha \beta^{-}$and $\mathrm{TCR} \alpha \beta^{\text {low }}$ thymocyte subpopulations. Thus the percentage of TCR $\alpha \beta^{\text {low }}$ thymocytes gradually rose (from $55.70 \%$ on day 1 to $68.62 \%$ on day $7 ; p<0.05$ ) while the percentage of TCR $\alpha \beta^{-}$thymocytes declined (from $37.61 \%$ on day 1 to $26.67 \%$ on day $7 ; p<0.05$; Table 2).

In respect to the expression of CD4 and CD8 molecules, and the level of TCR $\alpha \beta$ expression, twelve subsets of thymocytes were described and the relative proportion of thymocytes belonging to each of them was determined.

Compared to the control, the percentage of DN TCR $\alpha \beta^{-}$thymocytes was significantly decreased in the thymic lobes cultivated $1(p<0.001)$ and $3(p<0.05)$ days, while after 7 days of ATOC the percentage of the mentioned cells increased $(p<0.01)$. In addition, a significant decrease of DN TCR $\alpha \beta^{\text {low }}$ thymocytes $(p<0.01)$ in all investigated time points of culture was also detected. However, the high level of TCR $\alpha \beta$ expression within DN subpopulation in the cultivated thymic lobes was not detected (Table 2).

The analysis of DP thymocyte subpopulation showed that cultivation increased the percentage of DP TCR $\alpha \beta^{\text {low }}$ cells in all investigated time points of culture $(p<0.05$ on days 1 and $3 ; p<0.01$ on day 7$)$, but decreased the relative 
Acta Veterinaria (Beograd), Vol. 61, No. 5-6, 461-478, 2011.

Rakin K Ana et al.: Rat thymocytes differentiation

in adult thymus organ culture

proportion of DP TCR $\alpha \beta^{-}$thymocytes subset $(p<0.05$ on day 7$)$. The percentage of DP TCR $\alpha \beta^{\text {hi }}$ cells was unchanged (Table 2 ).

Table 2. Relative proportion of thymocytes, which express different levels of TCR $\alpha \beta$ $\left(\mathrm{TCR} \alpha \beta^{-}, \mathrm{TCR} \alpha \beta^{\text {low }}, \mathrm{TCR} \alpha \beta^{\text {hi }}\right)$, and the relative proportion of TCR $\alpha \beta^{-}, \mathrm{TCR} \alpha \beta^{\text {low }}$, TCR $\alpha \beta^{\text {hi }}$ thymocytes within four major thymocyte subpopulations in the controls and cultivated thymus lobes

\begin{tabular}{|c|c|c|c|c|}
\hline \multirow{2}{*}{$\begin{array}{l}\text { Thymocyte } \\
\text { subsets }\end{array}$} & \multicolumn{4}{|c|}{ Percentage of thymocytes } \\
\hline & Control & 1 day & 3 days & 7 days \\
\hline TCR $\alpha \beta^{-}$ & $42.22 \pm 1.4$ & $37.61 \pm 7.4$ & $33.98 \pm 6.6^{*}$ & $28.80 \pm 3.1^{*}$ \\
\hline TCR $\alpha \beta^{\text {low }}$ & $42.27 \pm 1.7$ & $56.70 \pm 7.3^{\star}$ & $60.70 \pm 6.5^{\star}$ & $65.87 \pm 3.7^{\star}$ \\
\hline TCR $\alpha \beta^{\text {hi }}$ & $15.54 \pm 0.5$ & $5.81 \pm 1.8^{* \star}$ & $5.34 \pm 1.3^{\star *}$ & $5.21 \pm 1.0^{* *}$ \\
\hline DN TCR $\alpha \beta^{-}$ & $2.64 \pm 0.03$ & $0.05 \pm 0.001 * * *$ & $0.97 \pm 0.03^{\star}$ & $5.33 \pm 0.93^{\star *}$ \\
\hline DN TCR $\alpha \beta^{\text {low }}$ & $0.82 \pm 0.002$ & $0.02 \pm 0.001^{* *}$ & $0.03 \pm 0.001^{* *}$ & $0.10 \pm 0.001 * *$ \\
\hline DN TCR $\alpha \beta^{\text {hi }}$ & $0.07 \pm 0.001$ & 0 & 0 & 0 \\
\hline DP TCR $\alpha \beta^{-}$ & $37.07 \pm 1.42$ & $29.74 \pm 0.95$ & $29.45 \pm 3.03$ & $22.20 \pm 0.87^{* *}$ \\
\hline DP TCR $\alpha \beta^{\text {low }}$ & $39.96 \pm 2.01$ & $49.92 \pm 3.12^{*}$ & $57.52 \pm 3.34^{*}$ & $65.15 \pm 4.25^{\star \star}$ \\
\hline DP TCR $\alpha \beta^{\text {hi }}$ & $3.9 \pm 0.2$ & $4.85 \pm 0.52$ & $4.92 \pm 0.47$ & $5.22 \pm 0.61$ \\
\hline CD8 TCR $\alpha \beta^{-}$ & $1.95 \pm 0.07$ & $3.91 \pm 0.11^{*}$ & $1.83 \pm 0.03$ & $0.81 \pm 0.036$ \\
\hline CD8 TCR $\alpha \beta^{\text {low }}$ & $0.6 \pm 0.001$ & $1.31 \pm 0.03$ & $0.59 \pm 0.02$ & $0.29 \pm 0.009$ \\
\hline CD8 TCR $\alpha \beta^{\text {hi }}$ & $3.79 \pm 0$ & $0.08 \pm 0.001^{* * *}$ & $0.08 \pm 0.001^{* * \star}$ & 0 \\
\hline CD4 TCR $\alpha \beta^{-}$ & $0.59 \pm 0.03$ & $3.89 \pm 0.83^{\star \star}$ & $1.73 \pm 0.18^{\star}$ & $0.46 \pm 0.09$ \\
\hline CD4 TCR $\alpha \beta^{\text {low }}$ & $0.89 \pm 0.04$ & $5.44 \pm 0.86^{\star \star}$ & $2.56 \pm 0.72$ & $0.33 \pm 0.001^{*}$ \\
\hline CD4 TCR $\alpha \beta^{\text {hi }}$ & $7.78 \pm 0.67$ & $0.88 \pm 0.002^{\star \star *}$ & $0.34 \pm 0.001^{\star \star \star}$ & 0 \\
\hline
\end{tabular}

The results are expressed as the mean \pm SD. ${ }^{*} p<0.05$; ${ }^{* *} p<0.01 ;{ }^{* \star} p<0.001$; v.s. control

After 1 day in ATOC the percentage of TCR $\alpha \beta^{-}$cells within SP CD8 ${ }^{+}$ subpopulation was significantly higher than in the controls $(p<0.05)$, while the percentage of CD8TCR $\alpha \beta^{\text {low }}$ cells remained unchanged. The percentage of SP $\mathrm{CD} 8^{+} \mathrm{TCR} \alpha \beta^{-/ / \text {low }}$ on days 3 and 7 of culture was not significantly different from control values. The population of the thymocytes bearing SP CD8TCR $\alpha \beta^{\text {hi }}$ phenotype showed a significant decrease $(p<0.001)$ after 1 and 3 days of cultivation, compared to controls. However, on day 7 of culture the high level of TCR $\alpha \beta$ expression within SP CD8 subpopulation was not detected (Table 2).

The analysis of the relative proportion of SP CD4TCR $\alpha \beta^{-/ l o w}$ cell subsets showed a significant increase after $1 \quad\left(p<0.01 \quad\right.$ CD4TCR $\alpha \beta^{-} ; \quad p<0.05$ CD4TCR $\left.\alpha \beta^{\text {low }}\right)$ and $3\left(p<0.05\right.$ CD4TCR $\left.\alpha \beta^{-}\right)$days in culture compared to controls. However, the percentage of SP CD4TCR $\alpha \beta^{\text {low }}$ cells, on day 7 was lower than in controls $(p<0.05)$. The relative proportion of cells bearing SP CD4TCR $\alpha \beta^{\text {hi }}$ phenotype was significantly decreased on days 1 and $3(p<0.001)$ in ATOC, while 
on day 7 this subset was not detected (Table 2). It is obvious from the results presented above that the whole SP TCR $\alpha \beta^{\text {hi }}$ subsets diminished during the time of culturing. In order to investigate what is the fate of the most mature thymocyte subset we collected and analyzed cells from the culture media.

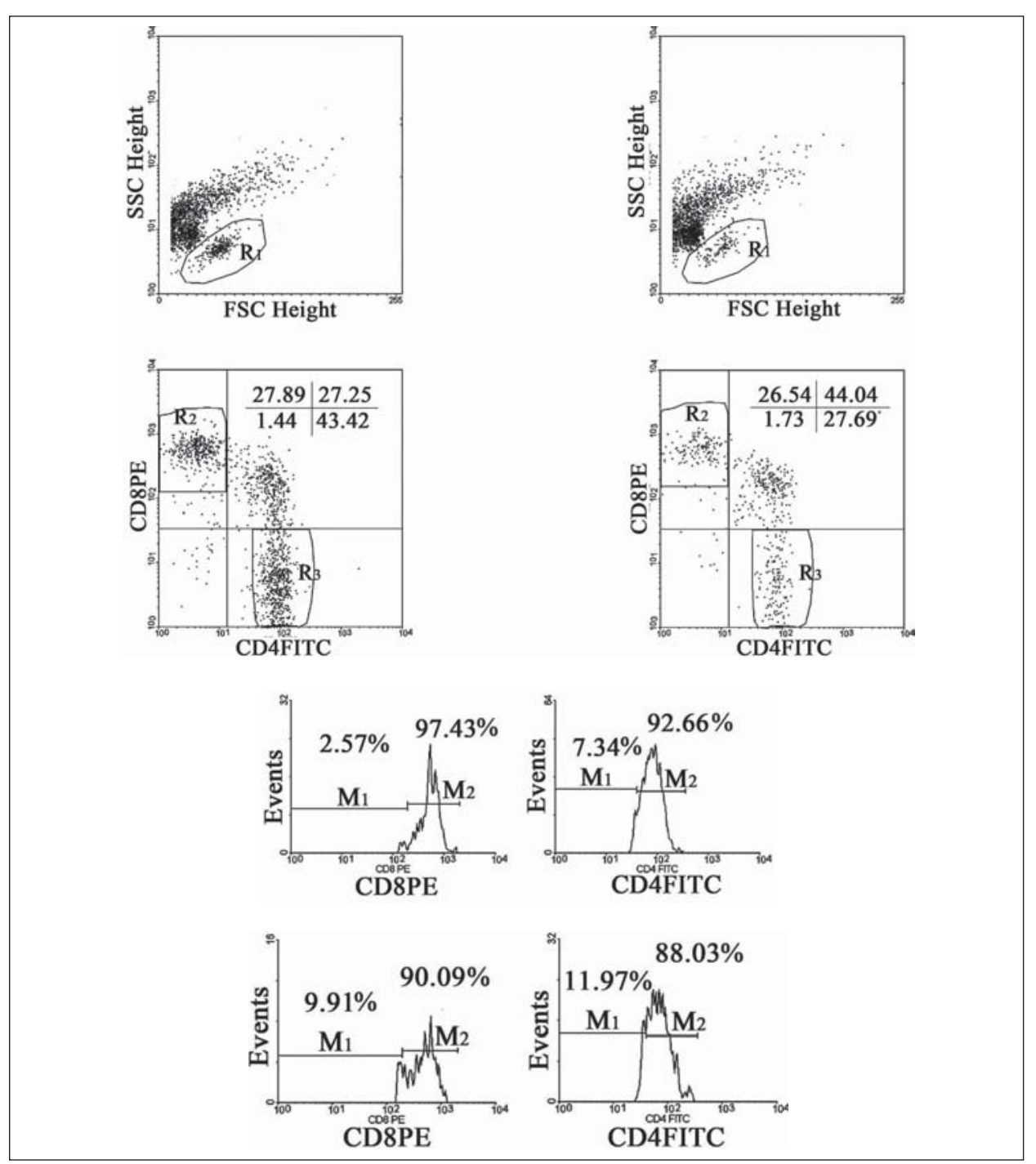

Figure 6. CD4 and CD8 expression on thymocyte "emigrants" after 1 and 3 days of culture (a): Quadrant 1- CD4-CD8+ : 2- CD4+CD8+; 3- CD4-CD8; 4- CD4+CD8-. Region R1 presents live thymocytes. Regions 2 and 3 represent SP CD8 and SP CD4 cells, respectively. Histograms show SP CD4 and SP CD8 expression on thymocytes collected from culture media used for 24 and 72 hours ATOC (b) 
Emigrants represented cells with predominantly mature phenotype

Culture media analysis revealed that after 24 hours in ATOC approximately $1 \%$ of thymocytes in the medium were DN, $27.75 \%$ DP, $27.89 \%$ CD8 SP and $43.42 \%$ CD4 SP. After 3 days in culture the percentage of thymocytes bearing CD4 phenotype within the SP cell compartment was significantly lower $(p<0.05)$, while the percentages of CD8 SP and DN subpopulations showed no variations, compared to the values obtained after 1 day in culture (Figure 6). Within both SP subpopulations the majority of cells belongs to mature CD8 or CD4 thymocyte subpopulations (Figure 6). Results obtained on day 7 of culture (data not shown) were similar to results obtained on day 3 .

\section{DISCUSSION}

Obtained results revealed that adult rat's thymic lobe fragments cultivation over the 7-day period in ATOC, same as in the controls leads to generation of mature SP thymocytes. However, a difference between these two systems exists in the thymocyte number and apoptotic cells percentage, thymocyte proliferation and relationship between thymocyte subpopulations.

During cultivation of the adult thymic lobe fragments the number of thymocytes significantly decreased. The greatest decline in cell number occurred during the first 4 days of culture, and this dramatic loss of cells during the first days of culture is consistent with the life span of thymocytes that fail to undergo positive selection (Merkenschlager et al., 1997; Ergoton et al., 1990; Surh and Sprent, 1994; Whalen et al., 1999). The number of viable cells in ATOC declines progressively over time in culture. Our results have shown that viable cells were present in cultivated thymic lobes after one week, which is supported by data obtained in adult diabetes-prone and diabetes-resistant BB rats ATOC (Whalen et al., 1999).

The decreased thymocyte number in the cultivated lobes might be a consequence of increased apoptosis and/or reduced proliferation. Our results show a significant increase of apoptotic cells over the 7-day period of culture compared to freshly isolated thymocytes. Whalen et al. (1999) described increase in the percentage of TUNEL ${ }^{+}$cells that remained elevated throughout the study. Interestingly, after 24 hours in ATOC about half of all thymocytes were either dead or dying by apoptosis. The extensive cell death detected in ATOC is consistent with the fact that, in normal rat thymus, $>97 \%$ of cells dies by neglect and negative selection (Gray et al., 2005; Ergoton et al., 1990). In addition, a reason for massive thymocytes death in ATOC might be depletion of energy reserves (Berger et al., 1987). Increased number of thymocytes with apoptotic morphological changes, in the cultivated thymic lobes, correlated with data obtained by flow cytometry using MC 540 dye. Johnson et al. (2000) showed that preapoptotic nuclear morphological changes preceded many of the biochemical features associated with apoptosis. Furthermore, biochemical features associated with apoptosis most probably originated from elevated cell cycle $S$ phase obtained in ATOC during culture time course. Finally, increase of thymocyte subsets containing

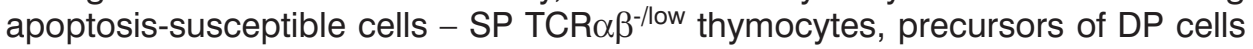


(Matsumoto et al., 1991; Sheard et al., 2004), most probably contributes to apoptotic cells number increase.

Our study also revealed that cultivation of thymic lobes in ATOC induced the formation of a distinct hypodiploid DNA-peak (sub-G1) accompanied with a decrease of the G0/G1 peak. Changes mentioned above contribute, at least partially, to total cell number reduction. These findings are in accordance with results described in diabetes-resistant BB rat ATOC (Whalen et al., 1999). However, the increased number of cells with hyperdiploid DNA content (S and G2/M cell cycle phases) indicates the possibility of cell division cycle prolongation, especially in the S phase, throughout the duration of the study. This prolongation might present additional time that enables cells to prepare for DNA synthesis and/or repair of DNA damage (Mazel et al., 1996).

The phenotypic analysis of thymocytes from ATOC showed that thymus supports normal T cell development, although the number of cells in each subpopulation was reduced significantly, as well as the absolute number of thymocytes, mainly as a consequence of cell number reduction in DP thymocytes subpopulation. This finding is in accordance with the fact that DP thymocytes are exquisitely sensitive to apoptotic signals and that in vitro most of them die within 72 hours (Sohn et al., 2003). Having in mind that the thymus in ATOC recapitulates faithfully normal T cell development, and that DP thymocytes have an average life span of 3.5 days (Whalen et al., 1999), the results obtained after 3 and 7 days in culture, might reflect ATOC property to induce thymocytes differentiation in vitro. Namely, the data mentioned above associated with our results, and the fact that in the thymus exists a specific need for thymic epithelial cells to induce differentiation (Anderson et al., 1994;1997), might indicate that differentiation in the latter culture period ( 3 and 7 days) is elicited by ATOC containing stromal cells. Moreover, we suppose that T cell differentiation detected in the first three days of ATOC is initiated by signals from thymic stromal cells mainly triggered before thymic lobes cultivation.

Interestingly, the percentage of DN thymocytes decreased after 24 hours of ATOC and afterwards gradually rises so that on day 7 of culture the percentage of these cells was increased. The down-regulation of CD4 and CD8 molecules on the dying DP thymocytes in culture (Kishimoto et al., 1995) might be the explanation for the above mentioned finding.

Analysis of TCR $\alpha \beta^{-}$cell subset showed that cultivation provokes a decrease of DN TCR $\alpha \beta^{-}$(on days 1 and 3), DN TCR $\alpha \beta^{\text {low }}$ and DP TCR $\alpha \beta^{-}$immature cells. Enhanced thymocyte apoptosis, decreased proliferation and/or increased rate of thymocyte transition in DP TCR $\alpha \beta^{\text {low }}$ thymocytes might be the reason for the decreased percentage of these cells. However, the increase in the percentage of cells within the DP TCR $\alpha \beta^{\text {low }}$ subset, which have to go throughout positive selection (Huang et al., 1996), unchanged DP TCR $\alpha \beta^{\text {hi }}$ cells that passed selection (Jameson et al., 1995), and the decrease of both SP TCR $\alpha \beta^{\text {hi }}$ cell subsets, over cultivating time, suggests slowed down T cell development in ATOC compared to data obtained in controls. In contrast, Whalen et al. (1999) describe the decline in the percentage of immature double-positive cells accompanied with a progressive increase in the percentage of mature TCR $\alpha \beta^{\text {hi }}$ and CD4 single 
positive cells, in both diabetes-resistant and diabetes-prone BB rat ATOC. The reason for this discrepancy may be, at least partly due to the separate analysis of thymocytes origin from the thymus lobes and media in the present study.

Taking into consideration that during organ culture of fetal thymic lobes, up to $5 \%$ of the thymic cells migrate out of the lobes (Skinner et al., 1989), we examined the properties of thymocytes that emigrate from ATOC in culture media, at various time points of organ culture. Thymic emigrants displayed mainly mature CD4 and CD8 phenotype and their ratio was 2:1, after 24 hours in culture. After 3 and 7 days in culture within the SP cell compartment the percentage of thymocytes bearing CD4 phenotype was significantly lower and the CD4/CD8 ratio was $1: 1$. It was previously shown that $S P T$ cells migrate from thymus fragments in culture media where the presence and action of an extrinsic chemoattractant was excluded (Poznansky et al., 2000). CD4 and CD8 cells expressing high level of TCR $\alpha \beta$ were detected to emigrate within 24 hours of positive selection (Lee et al., 2001; Poznansky et al., 2000). On day 5, the number of cells leaving the thymus lobes reached a maximum in fetal thymus organ culture (Varas et al., 1997). Interestingly, we found DN and DP thymocyte subpopulations in the culture media among thymus emigrants, as well. The above mentioned is in agreement with the results obtained by Kim et al., (1998), Lee et al. (2001), and Vianello et al., (2005) whom also found immature cells (DP and DN) among thymic emigrants at earlier time points of fetal thymus organ culture (FTOC).

The presented results demonstrate that adult thymic lobe fragments in ATOC support T cell development from DN over DP in SP thymocytes although thymocyte number is diminished. Accumulation of the cells which have to go throughout the positive selection process, unchanged the percentage of cells that pass positive selection associated with reduced number of mature CD4/CD8 cells indicate slowed down thymocyte maturation in ATOC. Our results suggest that a short-time thymus organ culture might be useful for examining the influence of neuropeptides, neurotransmitters and drugs on T cell pool maintenance under normal and pathological conditions with respect to modulation of $\mathrm{T}$ cell maturation as a consequence of cultivation.

\title{
ACKNOWLEDGEMENTS:
}

This work was supported by grants from the Serbian Ministry of Science, projects No. 175050 and 175053.

\author{
Address for correspondence: \\ Ana Rakin \\ Immunology Research Center "Branislav Jankovic" \\ Institute of Virology, Vaccines and Sera "Torlak" \\ Vojvode Stepe 458 \\ 11221 Belgrade, Serbia \\ E-mail: anasupermica@gmail.com
}




\section{REFERENCES}

1. Anderson G, Hare KJ, Platt N, Jenkinson EJ, 1997, Discrimination between maintenance- and differentiation-inducing signals during initial and intermediate stages of positive selection, Eur $J$ Immunol 27, 8, 1838-42.

2. Anderson G, Jenkinson EJ, 2000, Thymus organ cultures and T-cell receptor repertoire development, Immunology, 100, 405-10.

3. Anderson G, Lane PJL, Jenkinson EJ, 2007, Generating intrathymic microenvironments to establish T-cell tolerance, Nature Rev Immunol, 7, 12, 954-63.

4. Anderson G, Owen JJ, Moore NC, Jenkinson EJ, 1994, Thymic epithelial cells provide unique signals for positive selection of CD4 ${ }^{+} \mathrm{CD}^{+}$thymocytes in vitro, J Exp Med, 179, 6, 2027-31.

5. Berger NA, Berger SJ, Sudar DC, Distelhorst CW, 1987, Role of nicotinamide adenine dinucleotide and adenosine triphosphate in glucocorticoid induced cytotoxicity in susceptible lymphoid cells, J Clin Invest, 79, 6, 1558-63.

6. Cardoso RS, Magalhães DA, Baião AMT, Junta CM, Macedo C, Marques MMC et al., 2006, Onset of promiscuous gene expression in murine fetal thymus organ culture. Immunology, 119, 3, 36975.

7. Correia-Neves M, Mathis D, Benoist C, 2001, A molecular chart of thymocyte positive selection, Eur J Immunol, 31, 9, 2583-92.

8. Ergoton M, Scollay R, Shortman K, 1990, Kinetics of mature T-cell development in the thymus Kinetics of mature T-cell development in the thymus, Proc Nati Acad Sci USA, 87, 7, 2579-87.

9. Gray DH, Ueno T, Chidgey AP, Malin M, Goldberg GL, Takahama Y, Boyd RL, 2005, Controlling the thymic microenvironment, Curr Opin Immunol, 17, 2, 137-43.

10. Hare KJ, Jenkinson EJ, Anderson G, 1999, In vitro models of T cell development, Semin Immunol, 11, 1, 3-12.

11. Huang LY, van Meervijk MPJ, Bikoff EK, Germain RN, 1996, Comparison of thymocyte development in normal and invariant chain-deficient mice provides evidence that maturation-related changes in TCR and co-receptor levels play critical role in cell fate, Int Immunol, 8, 9, 1429-40.

12. Jameson SC, Hoquist KA, Bevan MJ, 1995, Positive selection of thymocytes, Ann Rev Immunol, 13, 93-126.

13. Jenkinson EJ, Anderson G, 1994, Fetal thymic organ cultures, Curr Opin Immunol, 6, 293-97.

14. Johnson VL, Ko SCW, Holmstrom TH, Eriksson JE, Chow SC, 2000, Effector caspases are dispensable for the early nuclear morphological changes during chemical-induced apoptosis, $J$ Cell Sci, 113, 17, 2941-53.

15. Kim CH, Pelus LM, White JR, Broxmeyer HE, 1998, Differential chemotactic behavior of developing T cells in response to thymic chemokines, Blood, 91, 12, 4434-43.

16. Kishimoto $H$, Surh $C D$, Sprent $J, 1995$, Upregulation of surface markers on dyin g thymocytes, $J$ Exp Med, 181, 2, 649-55.

17.Laakko T, King L, Fraker P, 2002, Versatility of merocyanine 540 for the flow cytometri c detection of apoptosis in human and murine cells, J Immunol Method, 261, 1-2, 129-39.

18. Lee CK, Kim K, Welniak LA, Murphy WJ, Muegge K, Durum SK, 2001, Thymic emigrants isolated by a new method possess unique phenotypic and functional properties, Blood, 97, 5, 1360-69.

19. Matsumoto K, Yoshikai Y, Moroi Y, Asano T, Ando T, Nomoto K, 1991. Two differential pathways from double negative to double positive thymocytes, Immunology, 72, 1, 20-6.

20. Mazel S, Burtrum D, Petrie HT, 1996, Regulation of cell division cycle progression by bcl-2 expression: a potential mechanism for inhibition of programmed cell death, J Exp Med, 183, 5, 2219-26.

21. Merkenschlager $M$, Graf D, Lovatt M, Bommhardt U, Zamoyska R, Fisher AG, 1997. How many thymocytes audition for selection? J Exp Med, 186, 7, 1149-58.

22. Mohtashami M, Zúñiga-Pflücker JC, 2006, Cutting Edge: Three-dimensional architecture of the thymus is required to maintain delta-like expression necessary for inducing $T$ cell development, J Immunol, 176, 2, 730-4. 
23. Mower AD, Peckham WD, Illera AV, Fishbaugh KJ, Stunz LL, Ashman FR, 1994, Decreased membrane phospholipid packing and decreased cell size precede DNA cleavage in mature mouse B cell apoptosis, J Immunol, 152, 10, 4832-42.

24. Plum J, De Smedt M, Verhasselt B, Kerre T, Vanhecke D, Vandekerckhove B et al., 2000. Human T lymphopoiesis. In vitro and in vivo study models, Ann NY Acad Sci, 917, 724-31.

25. Poznansky MC, Evans RH, Foxall RB, Olszak IT, Piascik AH, Hartman KE et al., 2000, Efficient generation of human T cells from a tissue-engineered thymic organoid, Nat Biotechnol, 18, 729-34.

26. Sheard MA, Liu C, Takahama Y, 2004, Developmental status of CD4 ${ }^{-} \mathrm{CD} 8^{+}$and $\mathrm{CD} 4^{+} \mathrm{CD} 8^{-}$ thymocytes with medium expression of CD3, Eur J Immunol, 34, 1, 25-35.

27. Skinner MA, Moflfalt L, Marbrook J, 1989, Development of thymocytes in organ culture: Migrant cells with natural killer cell characteristics, Immunol Cell Biol, 67, 2, 107-14.

28. Sohn JS, Rajpal A, Winoto A, 2003, Apoptosis during lymphoid development, Curr Opin Immunol, $15,2,209-16$.

29. Starr TK, Jameson SC, Hogquist KA, 2003, Positive and negative selection of T cells, Annu Rev Immunol, 21, 1, 139-76.

30. Surh CD, Sprent J, 1994, T-cell apoptosis detected in situ during positive and negative selection in the thymus, Nature. 372, 6501, 100-3.

31. Thomas-Vaslin V, Altes HK, de Boer RJ, Klatzmann D, 2008, Comprehensive assessment and mathematical modeling of T cell population dynamics and homeostasis, J Immunol, 180, 224050.

32. Van Parijs L, Biuckians A, Abbas AK, 1998, Functional roles of fas and Bcl-2-regulated apoptosis of T lymphocytes, J Immunol, 160, 5, 2065-71.

33. Varas A, Vicente A, Jiménez E, Alonso L, Moreno J, Muñoz JJ et al., 1997, Interleukin-7 treatment promotes the differentiation pathway of T-cell-receptor-áâ cells selectively to the $\mathrm{CD}^{+}{ }^{+}$cell lineage, Immunology, 92, 4, 457-64.

34. Vianello F, Kraft P, Mok YT, Hart WK, White N, Poznansky MC, 2005, CXCR4-dependent chemorepellent signal contributes to the emigration of mature single-positive CD4 cells from the fetal thymus, J Immunol, 175, 8, 5115-25.

35. Whalen BJ, Weiser P, Marounek J, Rossini AA, Mordes JP, Greiner DL, 1999, Recapitulation of normal and abnormal BioBreeding rat $T$ cell development in adult thymus organ culture, $J$ Immunol, 162, 4003-12.

36. Woods CC, Banks KE, Gruener R, DeLuca D, 2003, Loss of T cell precursors after space flight and exposure to vector-averaged gravity, FASEB J, 17,1526-8.

37. Zhang J, Gong Y, Shao X, Zhang R, Xu W., Chu Y et al., 2007. Asynchronism of thymocyte development in vivo and in vitro, DNA Cell Biol, 26, 1, 19-27.

\title{
DIFERENTOVANJE TIMOCITA U ORGAN KULTURI TIMUSA ODRASLIH PACOVA
}

\author{
RAKIN K ANA, KUŠTRIMOVIĆ Z NATAŠA, KOSEC JD, ŽIVKOVIĆ P IRENA, \\ JANKOVIĆ DI i MIĆIĆ V MILEVA
}

\section{SADRŽAJ}

Sa namerom da ispitamo razlike između in vivo i in vitro sazrevanja timocita gajili smo fragmente lobusa timusa poreklom od mužjaka Albino Oksford pacova, starih dvanaest nedelja, u vremenskom periodu od sedam dana. Nakon kultivacije određivani su vijabilnost, apoptoza i ćelijski ciklus timocita, kao i histološke 
osobine timusnog tkiva. Takođe je analizirano ispoljavanje markera diferentovanja CD4, CD8 and TCR $\alpha \beta$ na površini timocita metodom tečne citofluorometrije. Dobijeni rezultati su ukazali da sedmodnevna kultivacija dovodi do smanjenja broja ćelija u timusu usled povećane apoptoze, smanjene proliferacije i odsustva ulaska progenitora timocita. Tokom prvih 24 sata kultivacije ne dolazi do promena u odnosima timocitnih populacija. Međutim, duže vreme kultivacije - 3 i 7 dana moduliše relativne odnose između timocitnih subpopulacija - povećava se procenat DP TCR $\alpha \beta^{\text {low }}$, procenat DP TCR $\alpha \beta^{\text {hi }}$ timocita osteje nepromenjen, dok su procenti ćelija oba subseta SP TCR $\alpha \beta^{\text {hi }}$ smanjeni, mada je prisustvo pomenutih SP subsetova dominantno u medijumu za kultivaciju. Navedeni rezultati pukazuju da kultivisani fragmenti timusnog tkiva zadržavaju sposobnost da podrže sazrevanje timocita u jednostruko pozitivne T ćelije, mada je diferentovanje timocita donekle modulisano kultivacijom. 